\title{
ROLE OF L- AND T-TYPE CALCIUM CHANNELS IN REGULATION OF ABSENCE SEIZURES IN WAG/Rij RATS
}

Received March 18, 2013.

In chronic experiments on five groups of WAG/Rij rats (a genetic model of absence epilepsy; six animals in each group), we recorded EEG activity from the S1po cortical area through implanted electrodes and subjected the cortex to the action of four agents affecting L- and T-type calcium channels (injections through an implanted cannula). A blocker of L-type channels, verapamil hydrochloride, an agonist of these channels, Bay K8644, an antagonist of T-type calcium channels, L-ascorbate, and an agonist of the latter channels, PMA, were used. The parameters of 7- to $10-\mathrm{Hz}$ spike-wave discharges, SWDs, spontaneously generated in the cortex of this rat strain (frequency of SWDs, mean duration of the latter, and their number) were measured within the baseline interval (before injections) and within three subsequent 20-min-long post-injection intervals. Normal saline was injected in the control group. There were no significant differences in the mean peak frequency in SWDs between all examined groups $(P>0.05$ in all cases). Verapamil significantly (by more than $40 \% ; P<0.05)$ decreased the mean SWD duration throughout the entire period of post-injection observation. The dynamics of the Bay K8644 effects were rather similar, but the intensity of SWD duration changes was somewhat smaller. Both the above agents in the doses used dramatically decreased the number (frequency of appearance) of SWDs within the observation period. L-ascorbate also suppressed SWD generation. The duration of these phenomena decreased mildly, while their number dropped dramatically. In the PMA group, the number of SWDs increased significantly (by $50 \%, P<0.05$ ) within the first 20 -min-long interval, but this was not observed within subsequent intervals. These findings confirm that blocking or activating of L- and T-type $\mathrm{Ca}^{2+}$ channels in the S1po area (cortical focus area) can significantly control generation of SWDs during absence seizures. Possible mechanisms underlying actions of the tested agents are discussed.

Keywords: absence seizures, spike-wave discharges, WAG/Rij rats, L- and T-type calcium channels.

\section{INTRODUCTION}

Absence seizures are believed to be a phenomenon typical of generalized non-convulsive epilepsies. These events are characterized by some general features, like brief unresponsiveness to environmental stimuli and interruption of consciousness. Absence

\footnotetext{
${ }^{1}$ Neurosciences Research Center, Tabriz University of Medical Sciences, Tabriz, Iran.

${ }^{2}$ Drug Applied Research Center, Tabriz University of Medical Sciences, Tabriz, Iran.

${ }^{3}$ Institute Für Physiologie I, Westfälische Wilhelms-Universität, Münster, Germany, and Shefa Neuroscience Research Center, Tehran, Iran.

${ }^{4}$ Urmia Neurophysiology Research Ceter, Urmia University of Medical Sciences, Urmia, Iran.

Correspondence should be addressed to P. Shahabi

(e-mail: parvizshahabi@gmail.com).
}

seizures are characterized by symmetric, bilateral, and synchronous $3-\mathrm{Hz}$ spike-wave discharges (SWDs) [1]. In absence epilepsy, abnormal motor activities may not be recognized [2]. The annual incidence rate of absence epilepsy has been estimated to be about 1.2-7.1 per 100,000 in different populations [3].

Wistar Albino Glaxo Rijswijk (WAG\Rij) rats are described to be a genetic model for absence epilepsy; these animals exhibit $7-$ to $10-\mathrm{Hz}$ SWDs lasting from 1 to $30 \mathrm{sec}[4,5]$. SWDs are not generated during active wakefulness and REM sleep, but they occur in wakefulness with a low level of alertness [6]. Sixteen to twenty discharges per hour are usually recorded [7]. During seizures, WAG/Rij rats remain immobile and twitch their vibrissae and facial muscles [8]. In line with cortical focus theory and nonlinear association 
analysis of SWDs, the S1po is the initiation site for SWDs. Seizure activities that were produced in this zone disseminated quickly in other areas of the cortex and thalamus. It was found that injection of ethosuximide into the ventrobasal thalamus and RTN demonstrated a low efficacy in suppression of SWDs $[9,10]$.

There is strong evidence that entry of $\mathrm{Ca}^{2+}$ ions into neurons plays a significant role in generation of seizures [11]. Throughout epileptiform activity, intracellular $\mathrm{Ca}^{2+}$ concentration increases, while extracellular $\mathrm{Ca}^{2+}$ concentration is reduced [12]. Highand low-voltage-activated (HVA and LVA) calcium channels are involved in the regulation of neuronal excitability and production of absence SWDs. Highvoltage-activated calcium channels include different subunits $(\alpha, \beta, \gamma$, and $\sigma)$. In mammals, genome expression forms three large families of subtype $\beta 1$. Four different kinds of L-type HVA calcium channels belong to the Cav1 family (Cav1 through Cav1.4) [13]._Cav1.2 and Cav1.3 channels are located on neuronal membranes, generally on the dendrites [14]. In hippocampal neurons, calcium currents in cells depend mostly on the presence of L-type channels [15].

Low-voltage-activated T-type channels are monomers of $\beta_{1}$ subunit, and their activation results from relatively small membrane depolarization. Such channels are members of the $\mathrm{Ca}_{\mathrm{v}} 3$ family, and they are divided into three groups $\left(\mathrm{Ca}_{\mathrm{v}} 3.1-\mathrm{Ca}_{\mathrm{v}} 3.3\right)$ [13]. T-type calcium channels play key roles in the regulation of neuronal excitability. Hyperactivity of these channels causes some neurological disorders, such as absence seizures and neuropathic pains [16]. It was mentioned that the activity of T-type channels is increased in a mouse model of epilepsy [17].

In our study, we examined the role of L- and T-type calcium channels on SWDs recorded from the cortical S1po area in WAG/Rij rats. The experiment addressed an important question of how SWDs can be changed after injections of agents that effectively influence the above-mentioned channels. These are a blocker of L-type calcium channels, verapamil hydrochloride; an L-type channel agonist, Bay K8644 (methyl-1,4-dihydro-2,6-dimethyl-3-nitro-4-(2trifluoromethylphenyl)-pyridine-5-carboxylate), an antagonist of T-type calcium channels, L-ascorbate; and T-type channel agonist, PMA (phorbol 12-myristate 13 -acetate, a protein kinase $\mathrm{C}$ activator).

\section{METHODS}

Animals and Drugs. Experiments were carried out on $30 \mathrm{WAG} / \mathrm{Rij}$ rats (age from 4 to 6 months, body mass from 220 to $260 \mathrm{~g})$. Animals were maintained under standard lab conditions $\left(22^{\circ} \mathrm{C}\right.$, light/dark cycle $12 / 12 \mathrm{~h}$, and unlimited access to food and water until the presupposed time of experiment).

Bay K8644, verapamil, and PMA were purchased from Tocris (Great Britain), L-ascorbate was purchased from Sigma (USA). Verapamil and L-ascorbate were dissolved in $0.9 \%$ saline. For injections into the S1po cortex (in the volume of $1 \mu 1$ ), Bay K8644 was dissolved in $0.9 \%$ saline and ethanol. To inject $500 \mathrm{nM}$ PMA, a stock solution containing $2 \mathrm{mM}$ PMA in DMSO was dissolved in saline to the necessary concentration.

Surgical Procedure. Rats were anesthetized i.p. by ketamine $(80 \mathrm{mg} / \mathrm{kg})$ and xylazine $(5 \mathrm{mg} / \mathrm{kg})$ [18]. All animals were implanted with two cortical stainless steel electrodes for EEG recording and a cannula for drug injection. The coordinates of the cannula tip were the following: $2.1 \mathrm{~mm}$ posterior, $5.5 \mathrm{~mm}$ lateral to the bregma, and $4.0 \mathrm{~mm}$ vertical from the skull surface (according to the stereotaxic atlas [19]).

The monopolar EEG recording electrode was in the frontal cortical region of the right hemisphere (coordinates: $\mathrm{AP}=0.22, \mathrm{~L}=0.24$, and $\mathrm{V}=0.26$ ), while the reference electrode was in the occipital cortex. Electrodes were fixed in the sockets by pins. The cannula socket was fixed to the skull by dental cement.

Recording and Injection. After 1-week recovery from surgery, rats were settled in a Faraday cage, and EEG was recorded from freely moving animals. Spike-wave discharges (Fig. 1) were recorded $20 \mathrm{~min}$ before and three times within 20-min-long intervals after drug injections. Mild natural stimuli (moderate sound or touch) were applied to prevent the animal from sleeping. Separate groups of rats were used to characterize the effects of verapamil, Bay K8644, L-ascorbate, and PMA. For bilateral injection of $1 \mu 1$ of the solution, a $27 \mathrm{G}$ cannula needle in the guide cannula was connected to a $10 \mu 1$ Hamilton syringe. A dose of $22.4 \mu \mathrm{mol}$ of Bay K8644 was injected. The verapamil hydrochloride injection dose was $40 \mu \mathrm{mol}$. In addition, $500 \mathrm{nmol}$ of PMA and $100 \mu \mathrm{mol}$ of L-ascorbate were injected in the respective animal groups.

Statistical Analysis. For statistical analyses, SPSS13 software was used. Variables (mean within- 


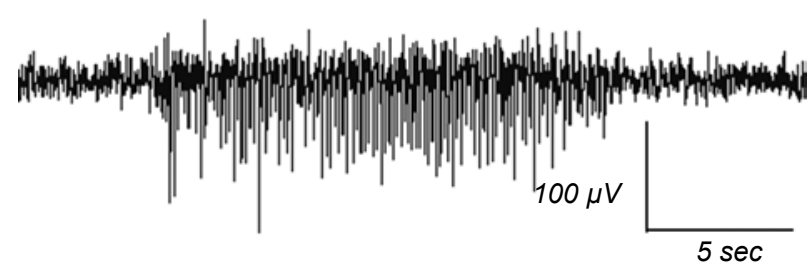

F i g. 1. Typical spike-wave discharge recorded from the S1po cortex of a WAG/ Rij rat.

Р и с. 1. Типовий розряд пік-хвиля, відведений від кортикальної зони S1po щура WAG/ Rij.

SWD peak frequency, mean duration, and number of SWDs) were analyzed by intragroup repeated measures and one-way ANOVA between groups. The Sidok test was applied for post-hoc analysis. Values were expressed as a percentage with respect to baselines. $P$ values smaller than 0.05 were considered statistically significant. The baseline was calculated as $100 \%$.

Histological Verification. After euthanizing the animals by a high dose of ketamine, we quickly removed the brains and fixed them in $10 \%$ formalin. The locations of the cannula tips were verified by cresyl violet staining in coronal sections of the brain.

\section{RESULTS}

To evaluate the effects of Bay K8644, verapamil, L-ascorbate, PMA, and control (saline) injections on SWDs, the mean peak frequency in these events, their mean duration, and number measured within three 20-min-long intervals after injection of the drugs were analyzed. The saline group served as the control. The data were averaged and presented as percentages of the baseline values taken as $100 \%$. During the baseline period, EEG was recorded for $20 \mathrm{~min}$, and the rats did not receive any drugs or saline.

Effects of Verapamil and Bay K8644 on SWDs. The SWD parameters during the above-mentioned 20-min-long periods for Bay K8644, verapamil, and control groups (six rats in each group) were compared using one-way ANOVA. No significant dissimilarities in the mean whithin-SWD peak frequency between experimental groups were found $(P<0.05)$.

In the control group, the mean SWDs within the first 20-min-long post-injection interval practically did not differ from the baseline value. Later on, a mild trend toward a decrease in this index was observed (Figs. 2A and $3 \mathrm{~A}$ ). At the same time, an analogous trend toward a decrease in the values of the mean number of SWDs was quite obvious throughout the entire post-injection observation period in the control (saline) group (Figs. 2B and 3B)

Comparison of the groups revealed remarkable effects of the agents on the number and duration of SWDs $(P<0.05)$. During the first 20 -min interval following injection of Bay K8644 and verapamil, the mean duration of SWDs in the Bay K8644 group was smaller than that in the control group $(71 \pm 13.5 \% v s$ $102 \pm 14.6 \%)$. In the verapamil group compared to the control group, an even greater $(56 \pm 12.8 \%$ vs $102 \pm$ $\pm 14.6 \%$ ) reduction of mean duration in the first 20 min phase was found.

The diference between the mean duration of SWDs in verapamil hydrochloride and control groups during the second and third 20 min was significant $(P<0.05)$. Within the second 20-min phase, the decrease in the SWD duration in the verapamil group was smaller compared to the control $(50.0 \pm 7.3$ and $86.0 \pm 6.5 \%$,
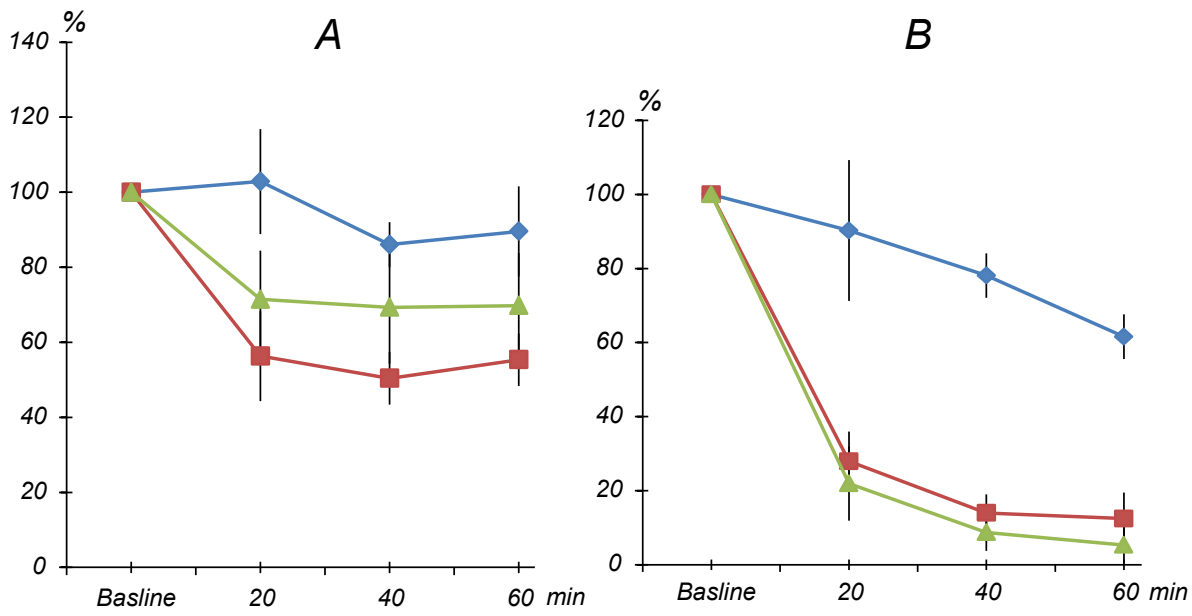

F i g. 2. Dynamics of the normalized effects (\%) of verapamil hydrochloride (40 $\mu \mathrm{mol}, 2)$ and Bay K8644 (22.4 $\mu \mathrm{mol}$, $3)$ on the duration $(A)$ and number $(B)$ of spike-wave discharges within three subsequent 20-min-long post-injection intervals. 1) Control. Baseline indices are taken as $100 \%$. Asterisks show cases of significant $(P<0.05)$ differences from the baseline values.

P и с. 2. Динаміка нормованих величин ефектів верапамілу гідрохлориду (40 мкмоль) та Вау К8644 (22.4 мкмоль) щодо тривалості $(A)$ та кількості $(B)$ розрядів пік-хвиля в межах трьох послідовних 20-хвилинних інтервалів після ін'єкцій. 

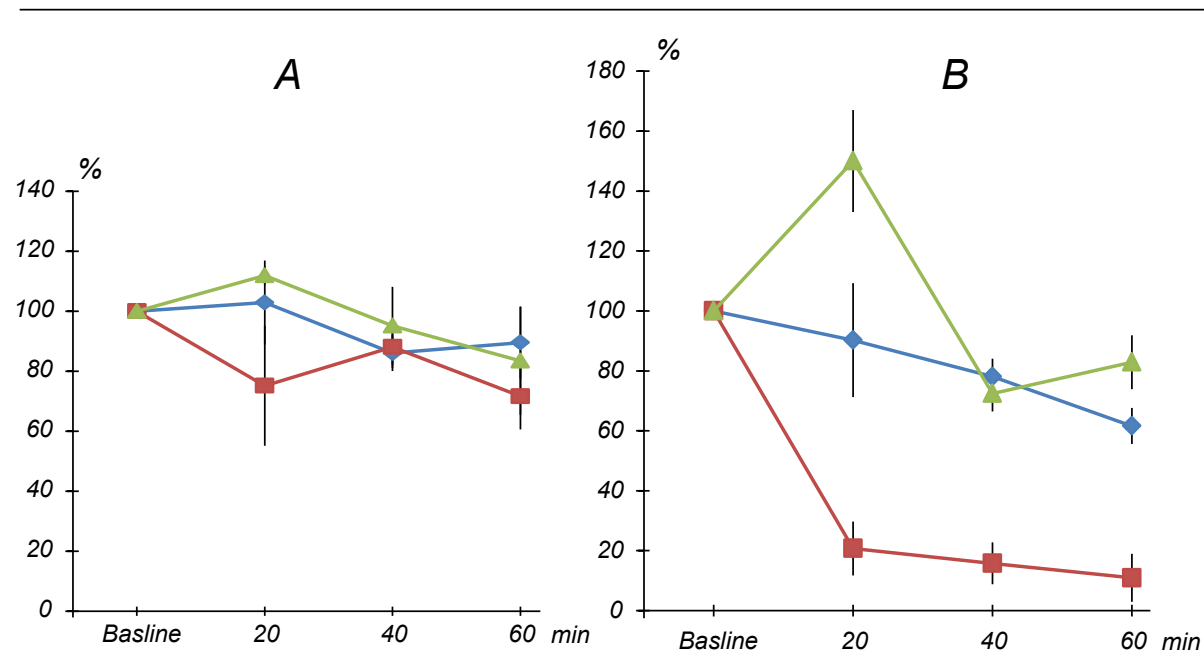

F i g. 3. Dynamics of the normalized effects of L-ascorbate $(100 \mu \mathrm{mol}, 2)$ and PMA $(500 \mathrm{nmol}, 3)$ on the duration $(A)$ and number $(B)$ of spike-wave discharges within the post-injection period. Other designations are similar to those in Fig. 2.

P и с. 3. Динаміка нормованих величин ефектів L-аскорбату (100 мкмоль) та PMA (500 нмоль) щодо тривалості $(A)$ та кількості $(B)$ РПХ у межах періоду спостереження після ін'єкцій.

respectively). During the third 20-min interval, there was also a decrease in the mean duration in comparison with the control group $(55 \pm 7.1$ and $89 \pm 12.6 \%$; Fig. 2A).

Injections of Bay K8644 also led to significant decreases in the mean duration of SWDs during the entire 60-min-long period of post-injection observation. The dynamics of changes in this index were rather similar to that in verapamil-injected rats, but the relative intensity of the drops was somewhat smaller (Fig. 2A).

In verapamil-injected animals, the mean numbers of SWDs were also dramatically smaller than those observed in control animals. The respective figures in the first $20 \mathrm{~min}$ were $27 \pm 8.51 \%$ vs $90 \pm 19.9 \%$, in the second 20 -min interval they were $14 \pm 5.9 \%$ vs $78 \pm 6.1 \%$, and in the third period they were $12 \pm 8.7 \%$ and $61 \pm 6.7 \%$ (Fig. 2B).

During the first, second, and third 20-min phases, considerable differences in the number of SWDs were also noted between the Bay K8644 and control groups. These were $21 \pm 11.0$ vs $90 \pm 19.9 \%, 8.0 \pm 5.1$ vs $78 \pm$ $\pm 6.1 \%$, and $5.0 \pm 5.1$ vs $61 \pm 7.0 \%$, respectively (Fig. 2B).

The results of three experimental groups compared using the repeated measures test showed that, during the first, second and third 20-min-long intervals after injection, there were no significant differences between the values of the mean peak frequency and mean duration of SWDs at these time points $(P>0.05$ in all cases).

Effects of L-Ascorbate and PMA on SWDs. Statistical analyses showed that the mean within SWD peak frequency did not change significantly in the L-ascorbate and PMA groups in comparison with the control group $(P>0.05)$. During the first 20 min post- injection, there was a noticeable decrease in the mean duration of SWDs in the L-ascorbate group and a mild trend toward increase in this index in the PMA group; the difference between these groups was significant $(75 \pm 21.0$ vs $109 \pm 3.6 \%)$. Within the second and third 20-min-long intervals after injections, the mean durations did not show significant differences between the three groups $(P>0.05$; Fig. 3A).

The mean number of SWDs during the first $20 \mathrm{~min}$ in the PMA group was significantly greater $(150 \pm$ $\pm 17.7 \%)$ compared to the control $(90 \pm 19.9 \%)$ and baseline values.

Within the subsequent period (second and third intervals of observation), the mean number of SWDs in the PMA group decreased below the baseline value (Fig. 3B).

Injections of L-ascorbate led to dramatic decreases in the mean number of SWDs within the entire period of 60-min-long post-injection observation. Within the first, second, and third 20-min-long intervals, the respective values were $20 \pm 9.2 \%, 15 \pm 7.4 \%$, and $10 \pm 8.5 \%$, as compared to the baseline value; all these figures were significantly smaller $(P<0.05)$ than the respective values in the control group (Fig. 3B).

All three consequent values of the normalized mean number of SWDs in the L-ascorbate group differed significantly $(P<0.05)$ from the corresponding values in the PMA group.

\section{DISCUSSION}

Calcium ions are significantly involved in the induction of SWDs in epilepsy. Extracellular $\mathrm{Ca}^{2+}$ enters via voltage-dependent calcium channels, like L- and T-type channels, across the plasma membrane 
and increases the $\mathrm{Ca}^{2+}$ concentration in excitable cells [20]. Our study was aimed at elucidating the role of the above calcium channels in the regulation of SWDs in WAG/Rij rats with absence seizures. For this purpose, verapamil, Bay K8644, L-ascorbate, and PMA were used. Our observations after microinjections of these drugs into the rat cortex showed that both Bay K8644 and verapamil reduced the mean duration and number of SWDs considerably. Injection of L-ascorbate decreased the number of SWDs, while increases in the mean duration and (especially) in the number of SWDs after receiving of PMA were found within the initial phase of observation.

In contrast to our results, a study on mice reported that when Bay K8644 was injected intracerebroventricularly (i.c.v), this agent produced seizure activity [21]. Furthermore, Bay K8644 increased calcium effects in an in vitro study on rat caudate neurons [22]. It was mentioned that, when introduced in the nucl. accumbens and bed nucl. stria terminalis, Bay K8644 exerted an activating effect on Cav1.3 [23].

Although Bay K8644 is an L-type $\mathrm{Ca}^{2+}$ channel opener and pro-convulsing drug, it does not have such an effect in all models [24]. Throughout the convulsion threshold test on mice, Bay K8644 did not demonstrate the above action. In genetically epilepsy-prone rats (GEPR) and DBAr2 mice, this drug could not cut down audiogenic seizures $[25,26]$. At the same time, Bay K8644 suppressed SWDs when administrated in a certain dose. In WAG/Rij rats, i.c.v. injections of high concentrations of Bay K8644 initiated convulsions, but administration of lower doses did not cause such an effect. As was reported earlier, administration of an L-type $\mathrm{Ca}^{2+}$ channel agonist, Bay K8644, suppresses SWDs, but dihydropyridines (L-type $\mathrm{Ca}^{2+}$ channel blockers) increase SWD incidence [27]. Experiments on rats [28] demonstrated that Bay K8644 suppresses SWDs, but administration of nimidipine (an L-type calcium channel antagonist) exerted a facilitating effect. The effect of Bay K8644 on SWDs in the cited report was also found in our study; thus, these data suggest that seizure activity can be reduced by the L-type $\mathrm{Ca}^{2+}$ channel activator Bay K8644. As was determined by experiments with administration of $\beta_{2}$-adrenergic agonists and GABA agonists, Bay K8644 exerts a dual action in epilepsy. In convulsive epilepsy, its action is pro-convulsing, but it demonstrates an antiepileptic activity in nonconvulsive epilepsy. The dual effect of Bay K8644 indicates that the respective mechanisms in convulsive and nonconvulsive epilepsy are different [28].

Verapamil is used in the treatment of hypertension (action on vascular smooth muscles) and epilepsy because it can block L-type $\mathrm{Ca}^{2+}$ currents in most cell types [29]. As was reported, this calcium channel blocker decreased the seizure frequency in a patient that suffered from refractory partial epilepsy [30]. In patients with the status epilepticus after i.v. administration of verapamil, consciousness was regained; according to EEG, no electrical manifestations of the above status were recognized [31]. Verapamil reduced the rate and duration of burst discharges in CA3 pyramidal cells in hippocampal slices [32]. In investigations on slices of the hippocampus and frontal neocortex, verapamil blocked epileptiform field potentials and paroxysmal depolarization shifts [33].

Verapamil reduces the $\mathrm{Ca}^{2+}$ level in the cytoplasm and induces repolarization in cells by preventing $\mathrm{Ca}^{2+}$ entry through calcium channels, influencing transmembrane $\mathrm{Na}^{+} / \mathrm{Ca}^{2+}$ exchange, and activating potassium channels sensitive to intracellular $\mathrm{Ca}^{2+}[34]$.

Redox agents, such as L-ascorbate, can change gating of T-type $\mathrm{Ca}^{2+}$ channels. $\mathrm{Ca}_{\mathrm{v}} 3.2$ can be inhibited by ascorbate, but this agent does not have any effect on $\mathrm{Ca}_{\mathrm{v}} 3.1$ and $\mathrm{Ca}_{\mathrm{v}} 3.3$ T-type channels. Regulation of the neuronal excitability depends on $\mathrm{Ca}_{\mathrm{v}} 3.2$ channels; so, ascorbate as a neuromodulator of these channels can be involved in modulation of neuronal firing. Ascorbate modulates T-currents and low-threshold spikes in nRT neurons $[35,36]$. In both extra- and intra-cellular brain spaces, ascorbate provides dynamic changes in physiological and pathophysiological situations [37].

The molecular mechanism that explains the inhibitory effect of L-ascorbate on $\mathrm{Ca}_{\mathrm{v}} 3.2$ channels is based on metal-catalyzed oxidation (MCO). During this process, reactive oxygen species (ROSs) produced by ascorbate oxidize a histidine residue in domain I S3-S4 region of the channels. Following oxidation of the $\mathrm{C} 2$ position of the histidine imidazole ring and formation of 2-oxo-histidine, calcium channels are blocked, and the $\mathrm{Ca}^{2+}$ intracellular concentration is reduced $[38,35]$.

Neurotransmitter and hormones can regulate T-channel activity through some signaling intermediates, like protein kinases A (PKA) and $\mathrm{C}$ (PKC) [39]. In an earlier study on rat dorsal root ganglion (DRG) neurons, it was shown that T-currents were inhibited after application of $10 \mathrm{~nm}$ PMA (an activator of PKC). In Purkinje cells from the canine heart and in the clonal GHs line of anterior pituitary 
cells, PKC activators inhibited T-currents [40, 41]. In parallel to our study, it is discovered that $\mathrm{Ca}_{\mathrm{v}} 3.2$ channel activities were increased by PMA in the Xenopus oocyte system. PMA activates PKC via phosphorylation of $\beta 1$ subunits in II-III loops of voltage-dependent calcium channels; this event activates these channels and increases calcium entry into neurons [42].

In conclusion, the data obtained in our study suggest that both BAY K8644 and verapamil hydrochloride reduce the incidence of SWDs in EEG of WAG/Rij rats by affecting the functioning of L-type calcium channels. L-Ascorbate blocks $\mathrm{Ca}_{\mathrm{v}} 3.2$ channels and reduces the number of SWDs. PMA provides phosphorylation of $\mathrm{Ca}_{\mathrm{v}} 3.2$ channels and increases seizure activity. Thus, both L- and T- type calcium channels play considerable roles in regulating of SWDs in absence seizures.

The experiments were carried out in accordance with the internationally accepted and institutional ethical norms related to the studies on vertebrate animals.

The authors, M. Sadighi, P. Shahabi, A. Gorji, G. Ghamkhari Nejad, and A. Ghorbanzade, have no conflict of interests.

This research was financially supported by the Neuroscience Research Center and Drug Applied Research Center of the Tabriz University of Medical Sciences (Tabriz, Iran, grant numbers 91-82-4 and 90-67-7).

М. Садігхі ${ }^{1}$ П. Шахабі ${ }^{2}$, А. Горджі ${ }^{3}$, Ф. Гхадері ${ }^{4}$, Г. Гамкхарі Неджад ${ }^{1}$, А. Горбанзаде

\section{РОЛЬ КАЛЬЦІЄВИХ КАНАЛІВ L- ТА Т-ТИПІВ У РЕГУЛЯЦІЇ АБСАНСНИХ СУДОМ У ЩУРІВ ЛІНІЇ WAG/ Rij}

\footnotetext{
${ }^{1}$ Дослідницький центр нейронаук Тебризького медичного університету (Іран).

${ }^{2}$ Центр прикладних досліджень фармакологічних агентів Тебризького медичного університету (Іран).

${ }^{3}$ Перший Інститут фізіології Вестфальського Університету Вільгельма, Мюнстер (ФРН) та Дослідницький Центр нейронаук Шефа, Тегеран (Іран).

${ }^{4}$ Дослідницький центр 3 нейрофізіології Медичного університету Урмії (Іран).

P е 3 ю м е
}

У хронічних експериментах на п'яти групах щурів лінії WAG/Rij (генетична модель абсанс-епілепсії; шість тварин у кожній групі) ми відводили ЕЕГ-активність від кортикальної зони S1ро через імплантовані електроди і піддавали кору дії чотирьох агентів, що впливають на кальцієві канали L- та Т-типів (ін'єкції через імплантовану канюлю).
Використовували блокатор кальцієвих каналів L-типу верапамілу гідрохлорид, агоніст цих каналів Вау K8644, антагоніст кальцієвих каналів T-типу L-аскорбат та агоніст останніх каналів РМА. Вимірювали параметри розрядів пік-хвиля (РПХ, частота 7-10 Гц), котрі спонтанно генеруються у корі головного мозку щурів указаної лінії (частоту в межах РПХ, середню тривалість останніх та їх кількість) протягом інтервалу порівняння (перед ін'єкціями) та трьох послідовних 20-хвилинних інтервалів після ін'єкцій. Щурам контрольної групи ін'єкували фізіологічний розчин. Істотних різниць між величинами частоти в межах РПХ у всіх досліджених групах не спостерігалося ( $P>0.05$ у всіх випадках). Верапаміл істотно (більш ніж на $40 \% ; P<0.05$ ) зменшував середню тривалість РПХ протягом усього періоду спостереження після ін'єкцій. Динаміка ефектів Вау К8644 була вельми подібною, але інтенсивність скорочення тривалості РПХ - дещо меншою. Обидва вказані агенти у використаних дозах зумовлювали драматичне зменшення кількості (тобто частоти виникнення) РПХ протягом усього періоду спостереження. L-аскорбат також істотно пригнічував генерацію РПХ. Тривалість цих феноменів зменшувалася помірно, а їх кількість скорочувалася дуже сильно. У групі РМА кількість РПХ протягом першого 20-хвилинного інтервалу спостереження істотно зростала (на $50 \%, P<0.05$ ), але цього не спостерігалося в межах наступних інтервалів. Наші результати підтверджують, що блокування або активація кальцієвих каналів L- та Т-типів у фокальній кортикальній зоні S1po здатні істотно контролювати генерацію РПХ під час прояву абсансних судом. Обговорюються можливі механізми дії тестованих агентів.

\section{REFERENCES}

1. A. Gorji, C Mittag, P. Shahabi, et al., "Seizure-related activity of intralaminar thalamic neurons in a genetic model of absence epilepsy," Neurobiol. Dis., 43, 266-274 (2001).

2. A. Amor, S. Baillet, V. Navarro, et al., "Cortical local and long-range synchronization interplay in human absence seizure initiation," NeuroImage, 45, 950-962 (2009).

3. E. Granieri, G. Rosati, R. Tola, et al., "A descriptive study of epilepsy in the district of Copparo," Epilepsia, 24, 502-514 (1983).

4. W. H. I. M. Drinkenburg, E. L. J. M. van Luijtelaar, J. V. W. Schaijk, and A. M. L. Coenen, "Aberrant transients in the EEG of epileptic rats: A spectral analytical approach," Physiol. Behav., 54, 779-783 (1993).

5. A. M. L. Coenen, W. H. I. M. Drinkenburg, M. Inoue, and E. L. J. M. van Luijtelaar, "Genetic models of absence epilepsy, with emphasis on the WAG/Rij strain of rats," Epilepsy Res., 12, 75-86 (1992).

6. J. Vieth, "Vigilance, sleep and epilepsy," Eur. Neurol., 25, 128133 (1986).

7. A. M. L. Coenen and E. L. J. M. van Luijtelaar, "The WAG/Rij rat model for absence epilepsy: Age and sex factors," Epilepsy Res., 1, 297-301 (1987).

8. K. Sarkisova and G. van Luijtelaar, "The WAG/Rij strain: A genetic animal model of absence epilepsy with comorbidity of depression," Prog. Neuropsychopharmacol. Biol. Psychiat., 35, 
76-845 (2011).

9. J. P. A. Manning, D. A. Richards, N. N. Leresche, et al., "Cortical area specific block of genetically determined absence seizure by ethosuximide," Neuroscience, 123, 5-9 (2004).

10. H. Meeren, G. van Luijtelaar, F. L. D. Silva, and A. Coenen, "Evolving concepts on the pathophysiology of absence seizures: Break the cortical focus theory," Arch. Neurol., 62, 371-376 (2005).

11. F. B. Meyer, R. E. Anderson, and F. W. Sharbrough, "Selective central nervous system calcium channel blockers: a new class of anticonvulsant agents," Mayo Clin. Proc., 61, 239-247 (1986).

12. U. Heinemann, H. D. Lux, and M. J. Gutnick, "Extracellular free calcium and potassium during paroxysmal activity in the cerebral cortex of the cat," Exp. Brain Res., 27, 237-243 (1977).

13. G. W. Zamponi, P. Lory, and E. Perez-Reyes, "Role of voltagegated calcium channels in epilepsy," Eur. J. Physiol., 460, 395403 (2010).

14. J. W. Hell, R. E. Westenbroek, C. Warner, et al., "Identification and differential subcellular localization of the neuronal class $\mathrm{C}$ and class D L-type calcium channel alpha 1 subunits," J. Cell. Biol., 123, 949-962 (1993).

15. A. J. Drysdale, D. Ryan, R. G. Pertwee, and B. Platt, "Cannabidiol-induced intracellular $\mathrm{Ca}^{2+}$ elevations in hippocampal cells," Neuropharmacology, 50, 621-631 (2006).

16. C. Mircea Iftinca and G. W. Zamponi, "Regulation of neuronal T-type calcium channels," Pharmacol. Sci., 30, 32-40 (2008).

17. H. Khosravani and G. W. Zamponi, "Voltage-gated calcium channels and idiopathic generalized epilepsies," Physiol. Rev., 86, 941-966 (2006).

18. S. Spasic, A. Kalauzi, S. Kesic, et al., "Surrogate data modeling the relationship between high frequency amplitudes and Higuchi fractal dimension of EEG signals in anesthetized rats," J. Theor. Biol., 289, 160-166 (2011).

19. G. Paxinos and C. Watson, The Rat Brain in Stereotaxic Coordinates, Acad. Press, Australia (1986).

20. F. Striggow and R. Bohnensack, "Verapamil and diltiazem inhibit receptor-operated calcium channels and intracellular calcium oscillations in rat hepatocytes," FEBS Lett., 318, 341344 (1993).

21. R. C. Shelton, J. A. Grebb, and W. J. Freed, "Induction of seizures in mice by intracerebroventricular administration of the calcium channel agonist Bay K8644," Brain Res., 402, 399-402 (1987).

22. E. Cherubini and L. Lanfumey, "An inward calcium current underlying regenerative calcium potentials in rat striatal neurons in vitro enhanced by Bay K 8644," Neuroscience, 21, 997-1005 (1987).

23. A. Hetzenauer, M. J. Sinnegger-Brauns, J. Striessnig, and N. Singewald, "Brain activation pattern induced by stimulation of L-type $\mathrm{Ca}^{2+}$-channels: contribution of $\mathrm{Ca}(\mathrm{V}) 1.3$ and $\mathrm{Ca}(\mathrm{V})$ 1.2 isoforms," Neuroscience, 3, 1005-1015 (2006).

24. G. B. De Sarro, C. Ascioti, E. D. Di Paola, et al., "Effects of antiepileptic drugs, calcium channel blockers and other compounds on seizures induced by activation of voltage dependent L calcium channel in DBAr2 mice," Gen. Pharmacol., 23, 1205-1216 (1992).

25. S. J. Czuczwar, M. Gasior, W. A. Turski, and Z. Kleinrok, "Influence of a $\mathrm{Ca}^{2+}$ channel agonist, Bay K8644, on the anticonvulsant activity of NMDA and non-NMDA receptor antagonists," Eur. J. Pharmacol., 264, 103-106 (1994).
26. G. B. De Sarro, A. De Sarro, F. Federico, and B.S. Meldrum, "Anticonvulsant properties of some calcium antagonists on sound-induced seizures in genetically epilepsy prone rats," Gen. Pharmacol., 21, 769-778 (1990).

27. G. van Luijtelaar, D. Wiaderna, C. Elants, and W. Scheenen, "Opposite effects of T- and L-type $\mathrm{Ca}^{2+}$ channel blockers in generalized absence epilepsy," Eur. J. Pharmacol., 406, 381389 (2000).

28. E. L. J. M. van Luijtelaar, N. Ates, and A. M. L. Coenen, "Role of L-type calcium channel modulation in nonconvulsive epilepsy in rats," Epilepsia, 36, 86-92 (1995).

29. D. J. Triggle, "Calcium-channel drugs: structure-function relationships and selectivity of action," J. Cardiovascul. Pharmacol. 18, 1-6 (1991).

30. M. A. Summers, J. L. Moore, and J. W. McAuley, "Use of verapamil as a potential p-glycoprotein inhibitor in a patient with refractory epilepsy," Ann. Pharmacother., 38, No. 10, 1631-1634 (2004).

31. P. Iannetti, A. Spalice, and P. Parisi, "Calcium-channel blocker verapamil administration in prolonged and refractory status epilepticus," Epilepsia, 46, 967-969 (2005).

32. G. Aicardi and P. A. Schwartzkroin, "Suppression of epileptiform burst discharges in CA3 neurons of rat hippocampal slices by the organic calcium channel blocker, verapamil," Exp. Brain Res., 81, 288-296 (1990).

33. H. Straub, R. Kohling, and E. J. Speckmann, "Picrotoxininduced epileptic activity in hippocampal and neocortical slices (guinea pig): suppression by organic calcium channel blockers," Brain Res., 658, 119-126 (1994).

34. P. lannetti, P. Parisi, A. Spalice, et al., "Addition of verapamil in the treatment of severe myoclonic epilepsy in infancy," Epilepsy Res., 85, 89-95 (2009).

35. M. T. Nelson, P. M. Joksovic, P. Su, et al., "Molecular mechanisms of subtype-specific inhibition of neuronal T-type calcium channels by ascorbate," J. Neurosci., 27, 12577-12583 (2007).

36. E. M. Talley, L. L. Cribbs, J. H. Lee, et al., "Differential distribution of three members of a gene family encoding low voltage-activated (T-type) calcium channels," J. Neurosci., 19, 1895-1911 (1999).

37. M. E. Rice, "Ascorbate regulation and its neuroprotective role in the brain," Trends Neurosci., 23, 209-216 (2000).

38. M. C. Iftinca and G. W. Zamponi, "Regulation of neuronal T-type calcium channels," Trends Pharmacol. Sci., 30, 32-40 (2008).

39. T. Furukawa, H. Ito, J. Nitta, et al., "Endothelin-1 enhances calcium entry through T-type calcium channels in cultured neonatal rat ventricular myocytes," Circ. Res., 71, 1242-1253 (1992).

40. C. Marchetti and A. M. Brown, "Protein kinase activator 1-oleoyl-2-acetyl-sn-glycerol inhibits two types of calcium currents in GH3 cells," Am. J. Physiol. Cell Physiol., 254, 206210 (1988).

41. J. E. Schroeder, P. S. Fischbach, and E. W. McCleskey, "T-type calcium channels: heterogeneous expression in rat sensory neurons and selective modulation by phorbol esters," J. Neurosci., 10, 947-951(1990).

42. I. Y. Park, H. W. Kang, H. J. Moon, et al., "Activation of protein kinase $\mathrm{C}$ augments $\mathrm{T}$-type $\mathrm{Ca}^{2+}$ channel activity without changing channel surface density," J. Physiol., 2, 513523 (2006). 